\title{
Pharmacological screening and evaluation of antiplasmodial activity of Croton zambesicus against Plasmodium berghei berghei infection in mice
}

\author{
J.E. Okokon ${ }^{1}$, K.C. Ofodum ${ }^{1}$, K.K. Ajibesin², B. Danladi², K.S. Gamaniel ${ }^{3}$
}

${ }^{1}$ Department of Pharmacology \& Toxicology, Faculty of Pharmacy, University of Uyo, Uyo,Nigeria. ${ }^{2}$ Department of Pharmacognosy \&

Traditional Medicine, Faculty of Pharmacy, University of Uyo, Uyo, Nigeria.

${ }^{3}$ Department of Pharmacology, National Institute for Pharmaceutical Research and Development, Abuja,

Nigeria.

Received: 8.7.2004

Revised: 6.12.2004

Accepted: 12.12.2004

Correspondence to:

Okokon

E-mail: judeefiom@yahoo.com

\begin{abstract}
Objective: To evaluate the antiplasmodial activity of leaf extract of Croton zambesicus on chloroquine-sensitive Plasmodium berghei berghei infection in mice and to confirm its traditional use as a malarial remedy in Africa.

Materials and Methods: The ethanolic leaf extract of Croton zambesicus (50-200 mg/ kg) was screened for blood schizontocidal activity against chloroquine-sensitive Plasmodium berghei berghei infection in mice. The schizontocidal activity during early and established infections as well as the repository activity were investigated. Results: The extract demonstrated a dose-dependent chemosuppression or schizontocidal effect during early and in established infections, and also had repository activity. The activity was lower than that of the standard drugs (chloroquine $5 \mathrm{mg} / \mathrm{kg}$, pyrimethamine $1.2 \mathrm{mg} / \mathrm{kg} /$ day).

Conclusion: The leaf extract possesses considerable antiplasmodial activity, which can be exploited in malaria therapy.
\end{abstract}

KEY WORDS: Malaria, schizontocide.

\section{Introduction}

Croton zambesicus Muell Arg. (Euphorbiaceae) syn $C$. amabilis Muell. Arg.; syn. C. gratissimus Burch is an ornamental tree grown in villages and towns of Nigeria. It is a GuineoCongolese species widely spread in tropical Africa. The leaf decoction is used in Benin as antihypertensive and antimicrobial (urinary infections). ${ }^{[1]}$ The Ibibios in Uruan area of Akwa Ibom State of Nigeria use the leaf traditionally as a remedy for malaria. Block et al reported that ent-trachyloban -3ß-ol, a trachylobane diterpene, isolated from dichloromethane extract of the leaves has cytotoxic activity on HeLa cells. ${ }^{[2]}$ The alkaloidal fractions of the leaf have been reported to possess weak activity against Kelebsiella pneumoniae, Pseudomonas aeruginosa, Bacillis megaterium, Bacillus subtilis, Escherichia coli, Proteus mirabilis, Staphylococcus aureus, Aspergillus niger, Microsporum species and Penicillium species. ${ }^{[3]}$ The alkaloidal fractions of the stem have also been reported to be active against all micro-organisms mentioned above. ${ }^{[3]}$ The essential oil found in the leaves contains P cymene, linalool and beta-caryophyllene. ${ }^{[4]}$ The constituents of the essential oil also found in the flowering tops are pinene, limonene linalool, menthol, carvone, thymol, alpha - humulene and ceisnerolidol. ${ }^{[5]}$

In spite of the large number of phytochemical and pharmacological studies carried out worldwide on Croton zambesicus, no scientific report has been quoted in the index medicus and NAPRALERT database on the antiplasmodial activity of this plant grown in Nigeria. We, therefore, evaluated the blood schizontocidal activity of the leaf extract of $C$. zambesicus against Plasmodium berghei infection in mice.

\section{Materials and Methods}

\section{Plant}

The leaves of Croton zambesicus Linn (Euphorbiaceae) were collected in March 2003, at Uyo area of Akwa Ibom State, Nigeria and authenticated by Dr. Uduak Eshiet, a taxonomist in the department of Botany, University of Uyo, Uyo, Nigeria. A specimen was deposited at the Faculty of Pharmacy herbarium, University of Uyo, Uyo (Voucher no. FPUU 209.)

Preparation of extract

Material: The fresh leaves $(2 \mathrm{~kg})$ of the plant were shade 
dried for 8 days and then powdered. $100 \mathrm{~g}$ of the powder was macerated in ethanol $(300 \mathrm{ml})$ for $72 \mathrm{~h}$. The liquid extract obtained was concentrated in vacuum at $40{ }^{\circ} \mathrm{C}$. The yield was 3. $81 \%$.

Phytochemical screening: A preliminary phytochemical screening of the powdered material was carried out employing the standard procedures to reveal the presence of saponin, flavonoids, tannins, alkaloids and glycosides. ${ }^{[6,7]}$

\section{Animals}

Swiss albino mice (25-32 g) of both sexes were obtained from the University of Uyo animal house, Uyo, Nigeria. The animals were housed in standard cages and acclimatized for a period of 10 days. The mice were maintained on standard pelleted diet and water ad libitum. Approval for the study was obtained from the Animal Ethics Committee, University of Uyo.

\section{Parasite inoculation}

The chloroquine-sensitive Plasmodium berghei berghei strain was obtained from the National Institute of Pharmaceutical Research and Development, Abuja, Nigeria and was maintained in mice. The inoculum consisted of $5 \times 10^{7} P$. berghei berghei parasitized red blood cells per ml. This was done by determining both the percentage parasitaemia and the red blood cell count of the donor mouse using the hemocytometer and diluting the blood with isotonic saline in proportions indicated by both determinations. Each mouse was inoculated on day 0 , intraperitoneally, with $0.2 \mathrm{ml}$ of infected blood containing about $1 \times 10^{7}$ P. berghei berghei parasitized red blood cells obtained from a donor mouse having about $64.0 \%$ parasitaemia. ${ }^{[8]}$

Drug administration

The drugs and the extract used in this study were orally administered with the aid of a stainless metallic feeding cannula.

Evaluation of schizontocidal activity on early infection

A method described by Knight and Peters was used. ${ }^{[9]}$ The animals were divided into six groups of five mice each, and were administered 50,100,150 and $200 \mathrm{mg} / \mathrm{kg} /$ day doses of the extract, chloroquine $5 \mathrm{mg} / \mathrm{kg} /$ day and an equivalent volume of distilled water (control group) for four consecutive days (D0 to D3). On the fifth day (D4), thin blood films were made from the tail blood and fixed with methanol. The films were then stained with Giemsa stain and the percentage parasitemia was determined by counting the number of parasitized blood cells out of 500 red blood cells in random fields of the microscope. The average \% suppression of parasitemia was calculated in comparison to controls as shown below.

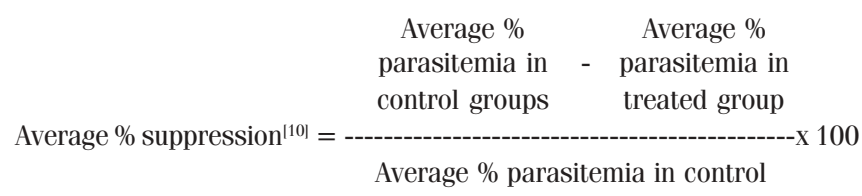

\section{Evaluation of the repository activity}

The repository activity was assessed by using the method described by Peters. ${ }^{[11]}$ The mice were divided into six groups of five animals each and administered 50, 100, 150 and 200 $\mathrm{mg} / \mathrm{kg} /$ day doses of the extract, $1.2 \mathrm{mg} / \mathrm{kg} /$ day pyrimethamine (standard group) and distilled water (control) for four consecutive days (D0 to D3). On day five (D4), the mice were inoculated with $P$. berghei berghei. Seventy-two hours later, the parasitemia level was assessed by blood smears.

Evaluation of schizontocidal activity in established infection (Rane test)

A modified method similar to Ryley and Peters was used. ${ }^{[12]}$ On D0, standard inocula of $1 \times 10^{7}$ infected erythrocytes was injected in mice, intraperitoneally. Seventy-two hours later, the mice were divided into six groups $(n=5)$. Different doses of C. zambesicus extract (50, 100, 150 and $200 \mathrm{mg} / \mathrm{kg} /$ day) were orally administered to these groups. Chloroquine $(5 \mathrm{mg} / \mathrm{kg} /$ day) was given to the standard group, and an equal volume of distilled water to the control group. The drug/extract was given once daily for 5 days. Thin films stained with Giemsa stain were prepared from tail blood for each mouse daily for 5 days to monitor the parasitemia level. The mean survival time for each group was determined arithmetically by finding the average of the survival time (days) of the mice (post inoculation) in each group over a period of 28 days (D0 to D28).

\section{Statistical analysis}

The data are expressed as mean \pm SEM. The data were statistically analysed using one-way ANOVA followed by TukeyKramer post test and values of $\mathrm{P}<0.05$ were considered significant.

\section{Results}

\section{Phytochemical screening}

Phytochemical screening of the ethanolic leaf extract of Croton zambesicus revealed the presence of compounds like saponins, alkaloids, terpenes, flavonoids and cardiac glycosides.

4-Day test

The ethanolic leaf extract of $C$. zambesicus produced a dose-dependent chemosuppressive effect at the different doses employed. (200, 150, 100 and $50 \mathrm{mg} / \mathrm{kg}$ doses with a chemosuppression of $80.7 \%, 75.0 \%, 70.7 \%$ and $38.4 \%$, respectively - Table 1). The standard drug, chloroquine $5 \mathrm{mg} /$ $\mathrm{kg} /$ day, caused $90 \%$ suppression [Table 1], which was significantly $(\mathrm{P}<0.05)$ more than that of the extract-treated groups.

\section{Repository test}

The ethanolic extract of $C$. zambesicus exerted a dosedependent repository activity at the various doses employed (200, 150, 100 and $50 \mathrm{mg} / \mathrm{kg} /$ day doses causing 78.5\%, 71.3\%, $63.0 \%$ and $50.0 \%$ chemosuppression, respectively - Table 2). However, the standard agent pyrimethamine $(1.2 \mathrm{mg} / \mathrm{kg} /$ day $)$ caused a considerably higher (89.93\%) chemosuppression than the extract-treated groups [Table 2] in which the highest dose produced $78.5 \%$ chemosuppression.

\section{Rane test}

There was a dose-dependent reduction in parasitaemia with the extract, similar to the chloroquine-treated group, while the control group showed a daily increase in parasitemia. However, there was a daily reduction in the parasitemia level of the chloroquine-treated group [Figure 1]. Data in Table 3 show that chloroquine $(5 \mathrm{mg} / \mathrm{kg} /$ day) gave a mean survival time (m.s.t) of $27.1 \pm 0.7$ days as compared to $11.5 \pm 3.5$, $20.5 \pm 0.6,21.3 \pm 0.8$ and $25.5 \pm 0.5$ days observed with 50,100 , 150 and $200 \mathrm{mg} / \mathrm{kg} /$ day doses of plant extract, respectively. It is noteworthy that some of the mice in the $200 \mathrm{mg} / \mathrm{kg} /$ day 
Table 1

Blood schizontocidal activity of $C$. zambesicus extract during early $P$. berghei berghei infection (4-day test) in mice

\begin{tabular}{|c|c|c|c|}
\hline $\begin{array}{l}\text { Drug/ } \\
\text { extract }\end{array}$ & $\begin{array}{c}\text { Dose } \\
\text { (mg/kg/day) }\end{array}$ & $\begin{array}{c}\text { Average \% } \\
\text { parasitemia }\end{array}$ & $\begin{array}{c}\text { Average \% } \\
\text { suppression }\end{array}$ \\
\hline C. zambesicus & 200 & $8.27 \pm 0.09^{*}$ & 80.7 \\
\hline \multirow[t]{3}{*}{ extract } & 150 & $10.68 \pm 0.21^{*}$ & 75.0 \\
\hline & 100 & $12.53 \pm 0.07^{*}$ & 70.7 \\
\hline & 50 & $26.34 \pm 1.73^{*}$ & 38.4 \\
\hline Chloroquine (standard) & 5 & $4.27 \pm 0.09$ & 90.0 \\
\hline Distilled water (control) & $0.2 \mathrm{ml}$ & $42.77 \pm 0.05$ & - \\
\hline One-way & & 133.70 & \\
\hline ANOVA & & $<0.05$ & \\
\hline
\end{tabular}

Data are expressed as mean \pm SEM for five animals per group; $d f=4,24 ;{ }^{*} P<0.05$ when compared to control.

Table 2

Repository activity of $C$. zambesicus extract against $P$. berghei berghei infection in mice

\begin{tabular}{|c|c|c|c|}
\hline $\begin{array}{l}\text { Drug/ } \\
\text { extract }\end{array}$ & $\begin{array}{c}\text { Dose } \\
\text { (mg/kg/day) }\end{array}$ & $\begin{array}{c}\text { Average } \% \\
\text { parasitemia }\end{array}$ & $\begin{array}{l}\text { Average \% } \\
\text { suppression }\end{array}$ \\
\hline C. zambesicus & 200 & $10.12 \pm 1.50^{*}$ & 78.5 \\
\hline \multirow[t]{3}{*}{ extract } & 150 & $13.49 \pm 7.38^{*}$ & 71.3 \\
\hline & 100 & $17.38 \pm 1.73^{*}$ & 63.0 \\
\hline & 50 & $23.54 \pm 1.91^{*}$ & 50.0 \\
\hline \multicolumn{2}{|c|}{ Pyrimethamine (standard) 1.2} & $4.74 \pm 1.02$ & 89.9 \\
\hline \multicolumn{2}{|c|}{ Distilled water (control) $0.2 \mathrm{ml}$} & $47.08 \pm 1.3$ & - \\
\hline One-way & & 3.176 & \\
\hline ANOVA & & $<0.05$ & \\
\hline
\end{tabular}

Data are expressed as mean \pm SEM for five animals per group; $d f=4,24 ;{ }^{*} \mathrm{P}<0.05$ when compared to control.

\section{Table 3}

Mean survival time of the mice receiving the various doses of ethanolic extract of $C$. zambesicus during an established $P$. berghei berghei infection in mice

\begin{tabular}{|c|c|c|}
\hline $\begin{array}{l}\text { Drug/ } \\
\text { extract }\end{array}$ & $\begin{array}{l}\text { Dose } \\
\text { (day) }\end{array}$ & $\begin{array}{c}\text { Mean survival time } \\
\text { (mg/kg/day) }\end{array}$ \\
\hline \multirow[t]{4}{*}{ C. zambesicus extract } & 50 & $11.5 \pm 3.51^{*}$ \\
\hline & 100 & $20.5 \pm 0.63^{*}$ \\
\hline & 150 & $21.3 \pm 0.81^{*}$ \\
\hline & 200 & $25.5+0.54^{*}$ \\
\hline Chloroquine (standard) & 5 & $27.5 \pm 0.73$ \\
\hline Distilled water (control) & $0.2 \mathrm{ml}$ & $7.5 \pm 0.76$ \\
\hline One-way & & 3.176 \\
\hline ANOVA & & $<0.05$ \\
\hline
\end{tabular}

Data are expressed as mean \pm SEM for five animals per group; $d f=4,24 ;{ }^{*} \mathrm{P}<0.05$ when compared to control.
Figure 1. Ethanolic extract of C. zambesicus on Rane test. Each point represents mean of 5 observations. Error bars represent SEM.

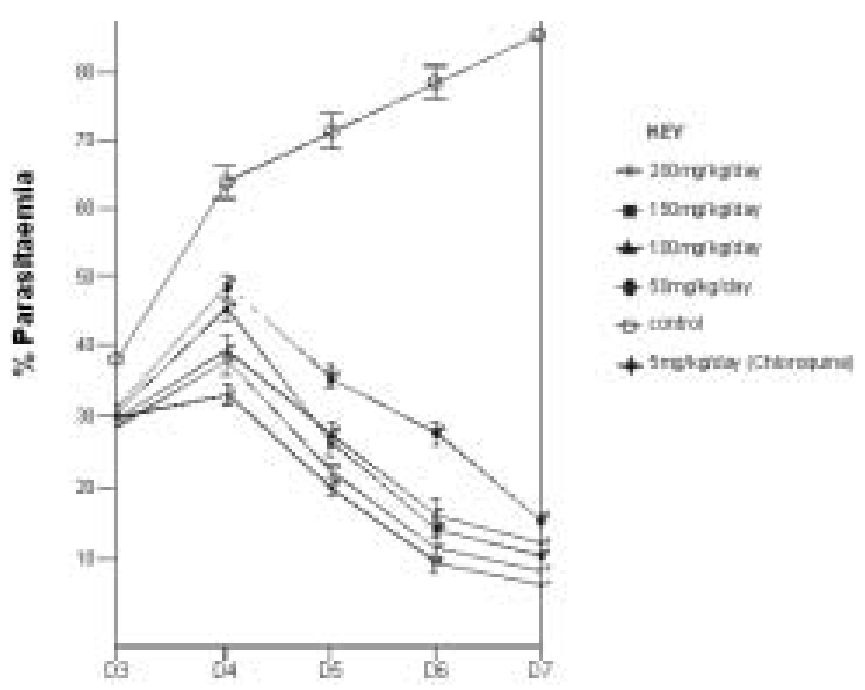

dose group survived the total duration of the study, as was the case with the chloroquine group. Although the values of m.s.t show that the plant extract significantly $(\mathrm{P}<0.05)$ suppressed established infection at the doses studied relative to the control group, they were lower than that induced by the group treated with the standard drug (chloroquine).

\section{Discussion}

In this study, preliminary phytochemical screening and evaluation of antiplasmodial activity of ethanolic leaf extract of Croton zambesicus were carried out. Alkaloids, terpenes and flavonoids, which have been variously implicated in antiplasmodial activities of many plants, ${ }^{[13]}$ are also found in the extract studied. The antiplasmodial activity observed in this study could have resulted from a single or combined action of these compounds. However, the active principle responsible is yet to be identified.

The results indicate that the leaf extract possessed blood schizontocidal activity as evident from the chemosuppression obtained during the 4-day early infection test. The plant extract also exhibited repository activity, though the doses used could not produce suppression comparable to that of the standard drug (pyrimethamine $1.2 \mathrm{mg} / \mathrm{kg} /$ day). However, on established infection, the plant extract exhibited significant $(\mathrm{P}<0.05)$ blood schizontocidal activity. It is noteworthy that the antiplasmodial activity of the extract at all doses during early and established infections was not comparable to that of the standard drugs. There was a dose-dependent chemosuppression of parasitemia seen with the extract. This was confirmed by the significant $(\mathrm{P}<0.05)$ high m.s.t values particularly in the group administered $200 \mathrm{mg} / \mathrm{kg} /$ day of the extract. The fact that some of the mice in this group survived throughout the 28 days of observation similar to the chloroquine-treated group shows a high level of efficacy of the extract, which was comparable to that of chloroquine, the referenced drug. 
The plant has exhibited promising antimalarial activity, which can be exploited in malaria therapy. However, in the course of the study it was discovered that the $5 \mathrm{mg} / \mathrm{kg} /$ day of chloroquine used as the standard in the 4-day test and Rane test did not cure the mice of malaria. This could be due to the development of resistance as the parasite is passaged from one mouse to another in the course of maintenance of the parasite strain. The extract and chloroquine doses tested in this study do not seem to be effective in chloroquine-resistant malaria. However, the possibility of increased doses of both the extract and chloroquine producing 100\% chemosuppression cannot be ruled out as this observation is based on the tested doses and also preliminary. The low doses of the extract in this preliminary study may have affected the results obtained with the tested extract in which curative activity could not be ascertained particularly in the two tests mentioned above. Although the mechanism of action of this extract has not been elucidated, some plants are known to exert antiplasmodial action either by causing elevation of red blood cell oxidation ${ }^{[14]}$ or by inhibiting protein synthesis ${ }^{[15]}$ depending on their phytochemical constituents. The extract could have exerted its action through either of the two mechanisms mentioned above or by some other unknown mechanism.

To conclude, the results of the present study have shown that the ethanolic leaf extract of Croton zambesicus possesses antimalarial activity as seen in its ability to suppress Plasmodium berghei berghei infection in mice in all the three evaluation tests. These observations confirm the traditional use of the plant to treat malaria. Therefore, it would be interesting if the active principle could be isolated, identified and characterized from this promising medicinal plant.

\section{Acknowledgments}

The authors are grateful to Dr. H.O.C. Mbagwu and Mr. Nsikan Malachy of the Dept. of Pharmacology and Toxicology, University of Uyo, Uyo, for their assistance.

\section{References}

1. Adjanohaun EJ, Adjakidje V, de Souza S. Contribution to Ethnobotanical and Floristic Studies in Benin Republic. Vol. 1 . Agency for Cultural and Technical Cooperation; 1989.

2. Block S, Stevigny C, De Pauw - Gillet MC, de Hoffman E, Llabres G, Adjakidje $V$, et al. ent-trachyloban-3ß-ol, a New Cytotoxic Diterpene from Croton zambesicus. Planta Medica 2002;68:647-8.

3. Abo KA, Ogunleye Ashidi JS. Antimicrobial Potential of Spondias mombin, Croton zambesicus, and Zygotritonia crocea. Phytotherapy Research 1999;13:494-7.

4. Menut C, Lamaty G, Bessiere JM, Suleiman AM, Fendero P, Maidou E, et al. Aromatic Plants of Tropical central Africa. XXII. Volatile constituents of Croton aubrevillei, J Leonard and C. zambesicus Muell. Arg J Essen Oil Resear 1995;7:419-22.

5. Mekkawi AG. The essential oil of Croton zambesicus. Fitoterapia 1985;56:1813.

6. Harbone JB. Phytochemical Methods. A guide to Modern Techniques of Plant Analysis. New York: Chapman and Hall; 1983

7. Evans WC. Trease and Evans Pharmacognosy. London: Bailliere tindall; 1987.

8. Odetola A, Bassir O. Evaluation of Antimalarial Properties of some Nigerian Medicinal Plants. In: Sofowora A, editor. Proceeding of African Bioscience Network, Fed. Min. of Science and Tech, Nigeria Soc. Of Pharmacolnosy and Drug Res. And Production Unit, University of Ife Organised Workshop, Ife; 1980.

9. Knight DJ, Peters W. The antimalarial action of N-benzyloxy dihydrotriazines.I. The actions of Clociguanil (BRL 50216) against rodent malaria and studies on its mode of action. Ann Trop Med Parasitol 1980;74:393-404.

10. Awe SO, Makinde JM. Antiplasmodial activity of Carica papaya against Plasmodium yoelli nigeriensis in mice. West Afr $\mathrm{J}$ Pharmacol Drug Res 1997;13:31-4.

11. Peters W. Drug resistance in Plasmodium berghei. Vincke and Lips, 1948: I chloroquine resistance. Expt Parasitol 1965;17:80-9.

12. Ryley JF, Peters W. The antimalarial activity of some quinolone esters. Am Trop Med Parasitol 1970;84:209-22.

13. Milliken W. Malaria and Antimalarial Plants in Roraima, Brazil. Trop Doct 1997;27:20-4

14. Etkin NL. Antimalarial Plants used by Hansa in Northren Nigeria. Trop Doct 1997;27:12-6.

15. Kirby GC, O'Neill MJ, Philipson JD, Warhurst DC. In vitro studies on the mode of action of quassionoids with activity against chloroquine-resistant Plasmodium falciparum. Biochem Pharmacol 1989;38:4367-74.

\title{
INTERNATIONAL WORKSHOP ON ADVERSE DRUG REACTION MONITORING
}

$\&$

$5^{\text {th }}$ ANNUAL CONFERENCE OF THE SOCIETY OF PHARMACOVIGILANCE

\author{
Date : $11-13^{\text {th }}$ November, 2005 \\ Venue : L.M. College of Pharmacy, Navrangpura, Ahmedabad
}

\section{Contact:}

\author{
Dr. D.D. SANTANI \& Dr. R.K. GOYAL \\ Organizing Secretaries \\ Department of Pharmacology, \\ L.M. College of Pharmacy, \\ Navrangpura, Ahmedabad-380 009. \\ E-mail: sopi5@rediffmail.com
}

